\title{
Molecular Characterization of Isolates of Fusarium spp. Associated With Wilt in Capsicum spp.
}

\author{
Isabela V. dos Anjos ${ }^{1}$, Suelene S. de Melo ${ }^{1}$, Thiago A. S. Gilio ${ }^{1}$, Jessé P. Kreitlow ${ }^{1}$, Sandra M. A. da S. Neves ${ }^{1}$, \\ Kelly L. Araújo ${ }^{1}$, Milson E. Serafim ${ }^{2} \&$ Leonarda G. Neves ${ }^{2}$ \\ ${ }^{1}$ School of Agronomy, Mato Grosso State University, Cáceres, Brazil \\ ${ }^{2}$ Federal Institute of Mato Grosso, Cáceres, Brazil \\ Correspondence: Isabela Vera dos Anjos, School of Agronomy, Mato Grosso State University, Cáceres \\ 78200-000, Brazil. Tel: 55-659-9969-3691. E-mail: iveradosanjos@hotmail.com
}

Received: February 1, 2019

doi:10.5539/jas.v11n6p519
Accepted: March 12, $2019 \quad$ Online Published: May 15, 2019

URL: https://doi.org/10.5539/jas.v11n6p519

\begin{abstract}
Fusarium is a diverse and heterogeneous fungi genus. Its wide genetic variability and similarity in morphological characteristics hinder the identification of species of this genus. Identifying Fusarium species is difficult due to the genus. Several molecular methods have been useful for differentiating these species, and the amplification of internal transcribed spacer (ITS) regions of the fungus ribosomal DNA has been successfully used, since ITS are preserved regions of the DNA that assists in distinguishing species. The objective of this work was to collect and characterize isolates of Fusarium spp. associated with wilt symptoms in Capsicum spp. in the biomes of the state of Mato Grosso, Brazil. Were collected tissue samples of plants with wilt symptoms. The DNAs of the Fusarium spp. found were extracted, and subjected to polymerase chain reaction, using the primers ITS1 (5'TCCGTAGGTGAACCTGCGG-3') and ITS4 (5'-TCCTCCGCTTATTGATATGC-3'). Subsequently, the sequencing was performed. The resulting sequences were, five Fusarium species were found $F$. solani, F. oxysporum, F. equiseti, F. incarnatum, F. chlamydosporum, predominating $F$. solani and F. equiseti.
\end{abstract}

Keywords: mycobank, genetic variability, pepper, wilt

\section{Introduction}

Fusarium is a diverse and heterogeneous fungi genus that is important in the food and drug industry, medicine, and agriculture (Luginbuhl, 2010). Fusarium species are worldwide spread; thus, this species have greater genetic, and pathogenic variability (Gonçalves, 2015). They are also known for their ability to cause several diseases in diverse hosts (Summerell et al., 2003).

Several pathogens cause wilt in Capsicum spp. (Ochoa \& Ramirez, 2001; Naik et al., 2008; Singh et al., 2017), however, wilt caused by Fusarium, especially Fusarium solani and Fusarium oxysporum, is the main disease in peppers and chilies, and a serious problem for these crops in the last years (Raghu et al., 2016; Tembhurne et al., 2017).

One of the predominant characteristics of Fusarium species is the formation of asexual spores-macroconidia and microconidia (Teixeira, 2015). They also produce resistance structures called chlamydospores (Bedendo, 1995), which assures their survival in plant and soil debris for many years and makes their control and eradication difficult (Raghu et al., 2016; El Kichaoui et al., 2017).

Identifying Fusarium species is difficult due to the genus amplitude and the lack of tools for a reliable differentiation of these species (Lievens et al., 2008). Moreover, distinguishing its species, formae speciales, and races is complicated, even for specialists (O'Donnell et al., 1998; Windels, 1991).

However, several molecular methods have been useful for differentiating these species (Kistler et al., 1987). The amplification of internal transcribed spacer (ITS) regions of the fungus ribosomal DNA (rDNA) has been successfully used for this purpose (Hillis \& Dixon, 1991; Menezes et al., 2010), since ITS are preserved regions of the DNA that assists in distinguishing species (Chen, 2004). ITS is located between the 18SrDNA and 28SrDNA genes, and this region can be divided into ITS1 (genes 18S to 5.8S) and ITS2 (genes 5.8S to 28S) (Hillis \& Dixon, 1991). Amplification of ITS regions is indicated for distinguishing species or varieties, because they are rapidly evolving regions (Fungaro, 2000). 
Thus, the objective of this work was to collect and characterize isolates of Fusarium spp. associated with wilt symptoms in Capsicum spp. in the biomes of the state of Mato Grosso, Brazil, creating a mycobank of high genetic variability.

\section{Method}

\subsection{Study Area}

Fusarium species were collected in five cities, representing the three biomes of the state of Mato Grosso, Brazil: Alta Floresta (Amazon), Cáceres (Pantanal), Juína (Cerrado), Mirassol d’Oeste (Amazon), Tangará da Serra (Amazon).

The morphological identification of the isolates from these collections was carried out in the Plant Breeding Laboratory of the Mato Grosso State University, Cáceres campus (PBL-UNEMAT). The molecular identification of the isolates, via sequencing of the ITS1 and ITS2 regions, was carried out by the company ACTGene Análise Moleculares Ltda., in the Biotechnology Center of the Federal University of Rio Grande do Sul, Porto Alegre RS, Brazil.

\subsection{Isolate Collection}

Producing farms of Capsicum spp. were visited and plants presenting the characteristic symptoms caused by Fusarium - wilt, yellowing, tipping, and stem base necrosis-were collected, packed, and sent to PBL-UNEMAT for further analysis and identification of the causal agent.

The areas evaluated were delineated using a GPS to obtain the geographical data of each collection point. Subsequently, these data were input into the ArcGis 10.1 software (Esri, Redlands CA, USA) to create a geographic database of the research.

\subsection{Pathogen Identification}

Stem and root samples of symptomatic plants were collected to isolate the pathogen (Figure 1). These samples were placed in Petri dishes containing PCNB-agar medium (Nash \& Snider, 1962) and incubated in BOD with photoperiod of 12 hours, at temperature of $25 \pm 2{ }^{\circ} \mathrm{C}$, for approximately seven days.

A.

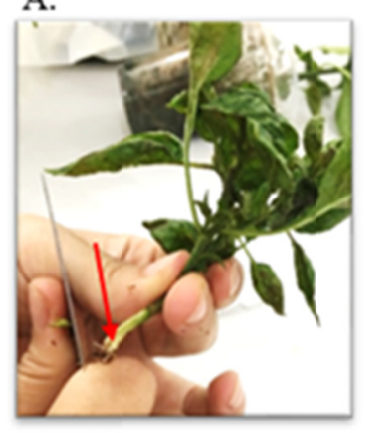

C.

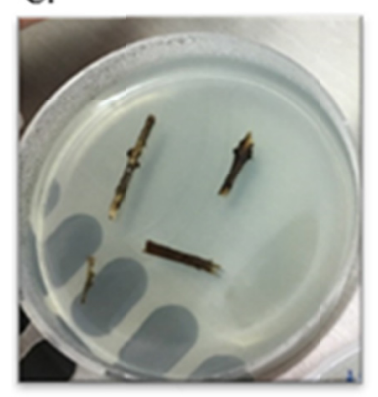

B.

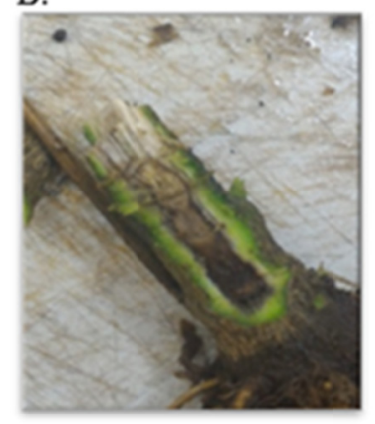

D.

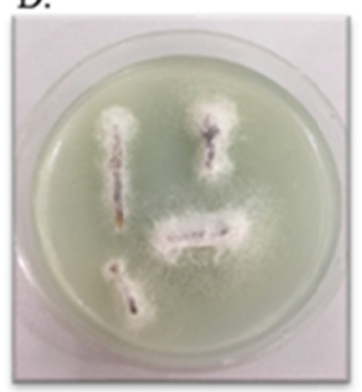

Figure 1. Isolation of symptomatic tissues of Capsicum spp. collected in the biomes of the state of Mato Grosso, Brazil. A) Segmentation of symptomatic root and stem base tissues; arrow showing an initial necrosis in the stem base; B) Stem showing necrosis; C) Fragments of symptomatic tissue in PCNB-agar medium; D) Mycelial growth after the incubation period 
The presence of pathogens was confirmed via morphological characterization of the isolates, which was carried out after their growth, in approximately 7 days, using a microscope. The characterization was based on colony coloration (Figure 2); presence, size, and shape of macroconidia and microconidia (Figure 3); presence and arrangement of chlamydospores; and type of phialides where the conidia were formed (Figure 4) (Nelson et al., 1983; Nirenberg, 1990).

A

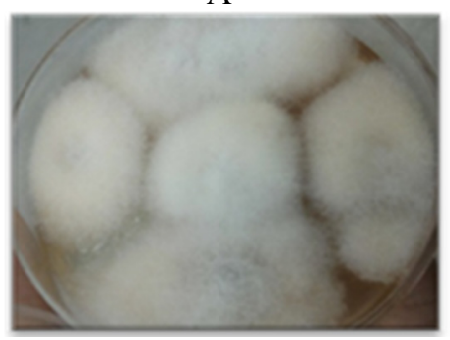

B

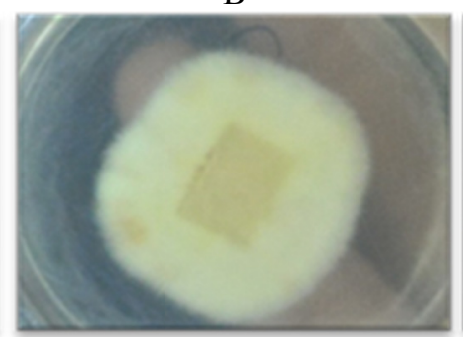

$\mathrm{C}$

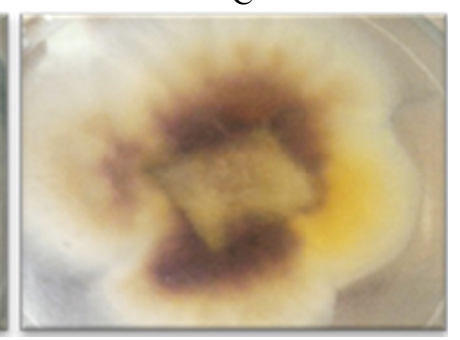

Figure 2. Coloration in PCNB-agar medium of colonies of Fusarium spp. collected from Capsicum spp. in the biomes of the state of Mato Grosso, Brazil. A) Petri dish with mycelial growth-upper perspective; B) Petri dish with light-colored mycelial growth-lower perspective; C) Petri dish with yellowish-purple mycelial growth-lower perspective

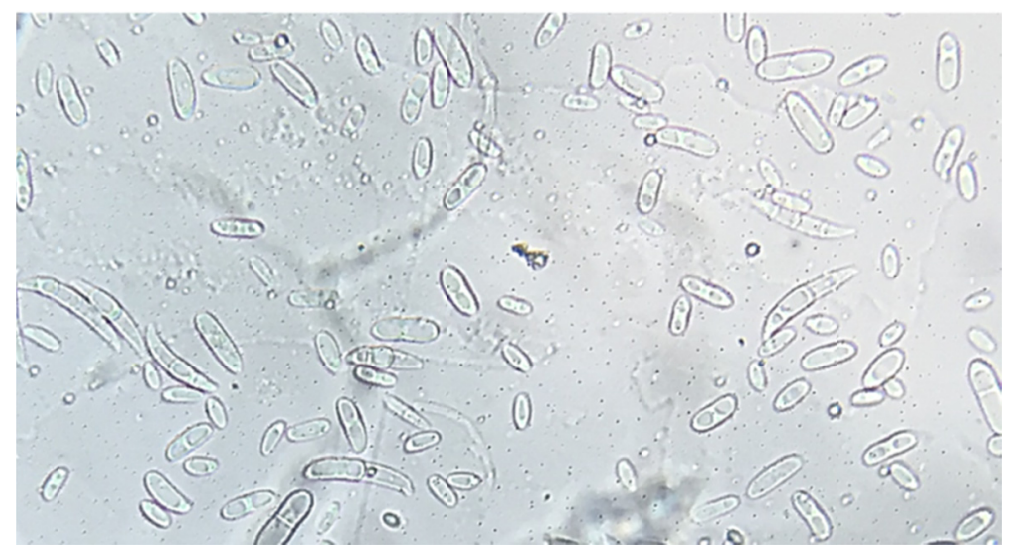

Figure 3. Macroconidia and microconidia of Fusarium spp. collected from Capsicum spp

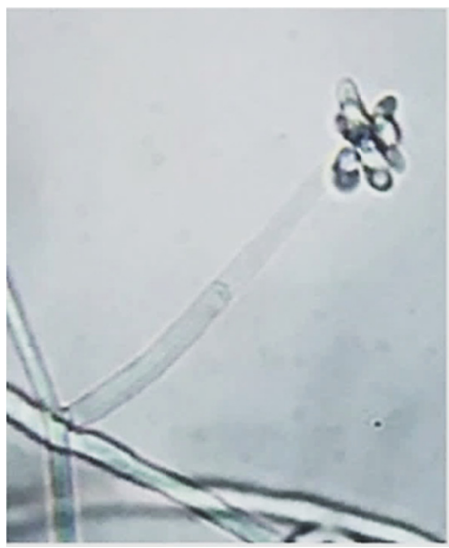

Figure 4. Phialides of Fusarium spp. collected from Capsicum spp

The isolates confirmed as Fusarium spp. were stored by the filter paper preservation method. Thus, small pieces of sterile filter paper were placed in a potato-dextrose-agar (PDA) culture medium, with mycelium of the isolate to be conserved, for a period of approximately 7 days. Subsequently, these papers were withdrawn and placed in 
sterile Petri dishes, which remained for approximately 7 days in BOD to reduce moisture. They were then sealed, stored in a refrigerator, and cataloged in the mycobank of the PBL-UNEMAT.

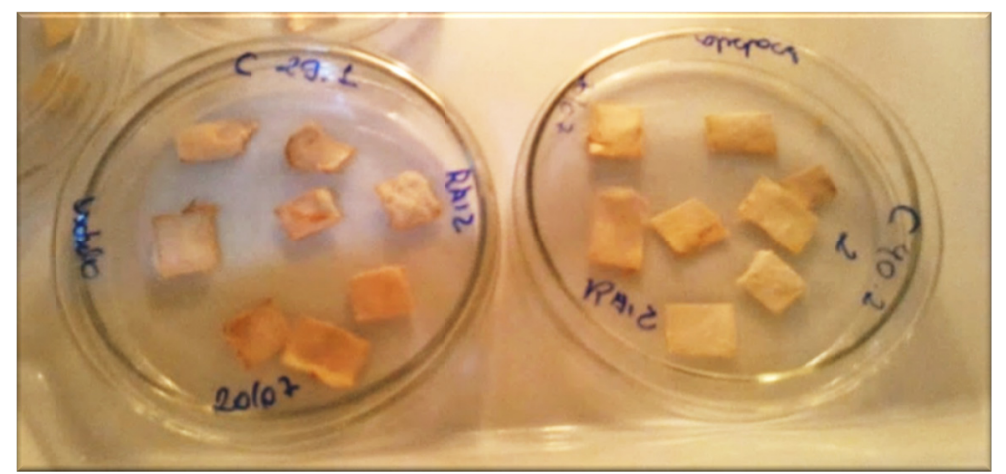

Figure 5. Isolates of Fusarium spp. collected in Capsicum spp. in the biomes of the state of Mato Grosso, Brazil, stored of in the mycobank of the Plant Breeding Laboratory of the Mato Grosso State University,

Cáceres campus

\subsection{Molecular Characterization}

The molecular characterization of the isolates of Fusarium spp. begun with DNA extraction from the collected isolates. Thus, the isolates of Fusarium spp. were cultured in Petri dishes with PDA medium for approximately 7 days. The mycelium was then withdrawn with spatulas and macerated in liquid nitrogen. The Wizard® Genomic DNA Purification Kit (Promega) and the protocol recommended by its manufacturer were used for the extraction.

The polymerase chain reactions (PCR) were carried out using $2 \mu \mathrm{L}$ of DNA from each isolate, $2.5 \mu \mathrm{L}$ of $10 \times$ PCR buffer, $2 \mu \mathrm{L}$ dNTP $(2.5 \mathrm{mM}), 1.25 \mu \mathrm{L}$ of each ITS primer, $0.125 \mu \mathrm{L}$ of Taq polymerase, and ultrapure $\mathrm{H}_{2} \mathrm{O}$ qsp to $25 \mu \mathrm{L}$. The protocol consisted in denaturation at $94{ }^{\circ} \mathrm{C}$ for $2 \mathrm{~min}$, followed by 35 cycles at $94{ }^{\circ} \mathrm{C}$ for 45 secs, $58{ }^{\circ} \mathrm{C}$ for $45 \mathrm{secs}$, and $72{ }^{\circ} \mathrm{C}$ for $1 \mathrm{~min}$, and elongation at $72{ }^{\circ} \mathrm{C}$ for $10 \mathrm{~min}$ in a thermal cycler. PCR products were subjected to electrophoresis in 1.5\% agarose gel. Amplicon sizes were determined with the 100pb DNA Ladder marker (Sigma-Aldrich Inc., St. Louis MO, USA).

The samples were then sequenced, and the molecular identification of the isolates was performed by partial sequencing of the ITS regions 1 and 2 of the rDNA, using the primers ITS1 (5'-TCCGTAGGTGAACCTGCGG -3') and ITS4 (5'-TCCTCCGCTTATTGATATGC-3') for the amplification of the rDNA ITS region (White et al., 1990). The sequences were compared with the GenBank database of the National Center for Biotechnology Information (NCBI) through the BLAST program. A phylogenetic tree with collected isolations and the references $F$. solani-MF401578.1, F. equiseti-MF471699.1, F. oxysporum-MG356946.1, F. chlamydosporumEU520242.1, F. incarnatum-MH045587.1. The phylogenetic tree were obtained using the analysis of Maximum Likelihood, The alignments and analysis were made using the software Mega 5.0 (Tamura et al., 2011).

\section{Results}

Eighty-nine plants of Capsicum spp., collected in the biomes of the state of Mato Grosso, presented characteristic symptoms of those caused by Fusarium-wilt, yellowing, tipping, and stem base necrosis. Fusarium spp. were found in 74 of these plants.

The geographic data of the collection points were used to develop a thematic map with the regions in which plants with Fusarium spp. were found (Figure 6). 


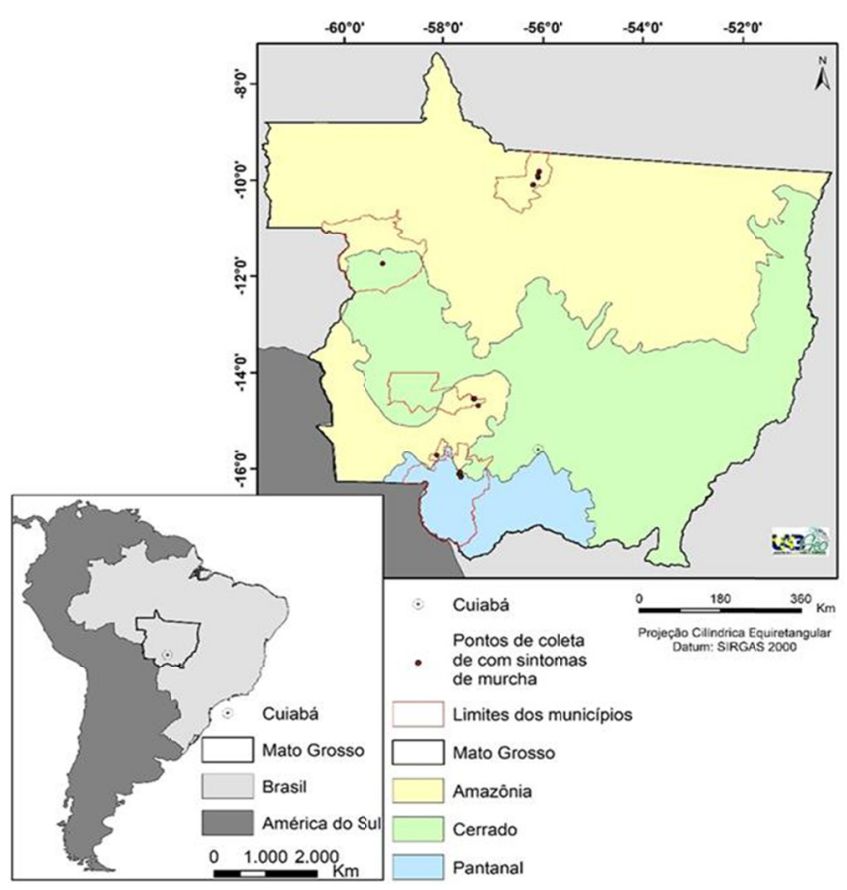

Figure 6. Map of collection points of Capsicum spp. in which Fusarium spp. were found

Based on the morphological data of the isolates, 26 isolates were selected for sequencing. The species of Fusarium spp. identified were Fusarium solani (10 isolates), Fusarium equiseti (10 isolates), Fusarium oxysporum (3 isolates), Fusarium incarnatum (2 isolates), and Fusarium chlamydosporum (1 isolate) (Table 1).

Table 1. Collected Coordinates points of Fusarium ssp. in plants of Capsicum spp. in three different biomes of Mato Grosso state

\begin{tabular}{|c|c|c|c|c|c|}
\hline Isolates & Cities & Biomes & CWWrdinates & & Species \\
\hline 1 & Cáceres & Pantanal & $16^{\circ} 9^{\prime} 46.05^{\prime \prime} \mathrm{S}$ & $57^{\circ} 38^{\prime} 10.38^{\prime \prime} \mathrm{W}$ & Fusarium solani \\
\hline 2 & Cáceres & Pantanal & $16^{\circ} 9^{\prime} 43.93^{\prime \prime} \mathrm{S}$ & $57^{\circ} 38^{\prime} 18.89^{\prime \prime} \mathrm{W}$ & Fusarium solani \\
\hline 3 & Cáceres & Pantanal & $16^{\circ} 9^{\prime} 41.83^{\prime \prime} \mathrm{S}$ & $57^{\circ} 38^{\prime} 18.20^{\prime \prime} \mathrm{W}$ & Fusarium equiseti \\
\hline 4 & Cáceres & Pantanal & $16^{\circ} 9^{\prime} 46.47^{\prime \prime} \mathrm{S}$ & $57^{\circ} 38^{\prime} 1.45^{\prime \prime} \mathrm{W}$ & Fusarium solani \\
\hline 5 & Cáceres & Pantanal & $16^{\circ} 10^{\prime} 43.03^{\prime \prime} \mathrm{S}$ & $57^{\circ} 38^{\prime} 21.96^{\prime \prime} \mathrm{W}$ & Fusarium solani \\
\hline 6 & Cáceres & Pantanal & $16^{\circ} 04^{\prime} 34.5^{\prime \prime} \mathrm{S}$ & $57^{\circ} 39^{\prime} 08.8^{\prime \prime} \mathrm{W}$ & Fusarium equiseti \\
\hline 22 & Cáceres & Pantanal & $16^{\circ} 04^{\prime} 34.5^{\prime \prime} \mathrm{S}$ & $57^{\circ} 39^{\prime} 08.8^{\prime \prime} \mathrm{W}$ & Fusarium solani \\
\hline 28 & Mirassol d'Oeste & Amazônia & $15^{\circ} 43^{\prime} 15.45^{\prime \prime} \mathrm{S}$ & $58^{\circ} 7^{\prime} 18.37^{\prime \prime} \mathrm{W}$ & Fusarium equiseti \\
\hline 29 & Cáceres & Pantanal & $16^{\circ} 6^{\prime} 39.92^{\prime \prime} \mathrm{S}$ & $57^{\circ} 40^{\prime} 48.85^{\prime \prime} \mathrm{W}$ & Fusarium solani \\
\hline 30 & Alta Floresta & Amazônia & $10^{\circ} 05^{\prime} 28.7^{\prime \prime} \mathrm{S}$ & $56^{\circ} 11^{\prime} 35.5^{\prime \prime} \mathrm{W}$ & Fusarium incarnatum \\
\hline 31 & Alta Floresta & Amazônia & $10^{\circ} 05^{\prime} 53.5^{\prime \prime} \mathrm{S}$ & $56^{\circ} 12^{\prime} 34.4^{\prime \prime} \mathrm{W}$ & Fusarium equiseti \\
\hline 34 & Alta Floresta & Amazônia & $09^{\circ} 55^{\prime} 56.6^{\prime \prime} \mathrm{S}$ & $56^{\circ} 04^{\prime} 04.0^{\prime \prime} \mathrm{W}$ & Fusarium equiseti \\
\hline 35 & Alta Floresta & Amazônia & $09^{\circ} 49^{\prime} 39.8^{\prime \prime} \mathrm{S}$ & $056^{\circ} 04^{\prime} 41.3^{\prime \prime} \mathrm{W}$ & Fusarium chlamydosporum \\
\hline 36 & Alta Floresta & Amazônia & $09^{\circ} 49^{\prime} 06.8^{\prime \prime} \mathrm{S}$ & $56^{\circ} 04^{\prime} 41.3^{\prime \prime} \mathrm{W}$ & Fusarium equiseti \\
\hline 37 & Alta Floresta & Amazônia & $09^{\circ} 48^{\prime} 39.9^{\prime \prime} \mathrm{S}$ & $56^{\circ} 04^{\prime} 51.6^{\prime \prime} \mathrm{W}$ & Fusarium oxysporum \\
\hline 38 & Alta Floresta & Amazônia & $09^{\circ} 56^{\prime} 37.5^{\prime \prime} \mathrm{S}$ & $56^{\circ} 05^{\prime} 56.5^{\prime \prime} \mathrm{W}$ & Fusarium oxysporum \\
\hline 39 & Alta Floresta & Amazônia & $09^{\circ} 54^{\prime} 29.3^{\prime \prime} \mathrm{S}$ & $56^{\circ} 06^{\prime} 36.8^{\prime \prime} \mathrm{W}$ & Fusarium equiseti \\
\hline 40 & Alta Floresta & Amazônia & $09^{\circ} 54^{\prime} 29.3^{\prime \prime} \mathrm{S}$ & $56^{\circ} 06^{\prime} 38.5^{\prime \prime} \mathrm{W}$ & Fusarium incarnatum \\
\hline 41 & Tangará da Serra & Amazônia & $14^{\circ} 32^{\prime} 58.6^{\prime \prime} \mathrm{S}$ & $57^{\circ} 22^{\prime} 52.8^{\prime \prime} \mathrm{W}$ & Fusarium equiseti \\
\hline 42 & Tangará da Serra & Amazônia & $14^{\circ} 32^{\prime} 17.1^{\prime \prime} \mathrm{S}$ & $57^{\circ} 23^{\prime} 11.1^{\prime \prime} \mathrm{W}$ & Fusarium oxysporum \\
\hline 43 & Tangará da Serra & Amazônia & $14^{\circ} 32^{\prime} 17.7^{\prime \prime} \mathrm{S}$ & $57^{\circ} 22^{\prime} 41.2^{\prime \prime} \mathrm{W}$ & Fusarium equiseti \\
\hline 44 & Tangará da Serra & Amazônia & $14^{\circ} 32^{\prime} 51.7^{\prime \prime} \mathrm{S}$ & $57^{\circ} 22^{\prime} 19.8^{\prime \prime} \mathrm{W}$ & Fusarium solani \\
\hline 46 & Cáceres & Pantanal & $16^{\circ} 04^{\prime} 34.1^{\prime \prime} \mathrm{S}$ & $57^{\circ} 39^{\prime} 07.6^{\prime \prime} \mathrm{W}$ & Fusarium solani \\
\hline 48 & Juína & Cerrado & $11^{\circ} 44^{\prime} 50.13^{\prime \prime} \mathrm{S}$ & $58^{\circ} 71^{\prime} 50.21^{\prime \prime} \mathrm{W}$ & Fusarium solani \\
\hline 49 & Cáceres & Pantanal & $16^{\circ} 04^{\prime} 34.1^{\prime \prime} \mathrm{S}$ & $57^{\circ} 39^{\prime} 07.6^{\prime \prime} \mathrm{W}$ & Fusarium equiseti \\
\hline 50 & Cáceres & Pantanal & $16^{\circ} 04^{\prime} 34.1^{\prime \prime} \mathrm{S}$ & $57^{\circ} 39^{\prime} 07.6^{\prime \prime} \mathrm{W}$ & Fusarium solani \\
\hline
\end{tabular}


The results obtained after sequencing the 26 isolates were used to create a phylogenetic tree of isolates, which showed how these isolates are grouped; they formed four distinct groups (Figure 7).

\section{Discussion}

The Group I consisted of ten Fusarium equiseti isolates found in the Amazon and Pantanal biomes, and two Fusarium incarnatum and one Fusarium chlamydosporum isolate found only in the Amazon biome. Reports on these isolates are scarce in scientific literature.

Although, Group II consisted of three isolates of Fusarium oxysporum, which were found only in the Amazon biome. This species, commonly confused with $F$. solani, is the causal agent of various vascular diseases in wilting plants. It has specific characteristics that is depended on its hosts, thus, it presents more than 100 formae speciales, and different races (Leslie \& Summerell, 2006). This pathogen was found in plants of Capsicum annuum in Mexico (Vásques Lopes et al., 2009), Spain (Martinez et al., 2010), and Pakistan (Sahi \& Khalid, 2007).

The Group III consisted of all the isolates characterized as Fusarium solani. Based on the geographic data, F. solani was found in plants of Capsicum spp. in the three biomes of the state of Mato Grosso, Amazônia, Pantanal and Cerrado.

Occurrence of Fusarium solani is found in several crops in Brazil, such as Piper nigrum (black pepper) (Rocha et al., 2015), and Passiflora spp. (Carvalho, 2015, Silva et al., 2014). However, no study on pathogens of the genus Fusarium was conducted with plants of Capsicum spp. Reports on the occurrence of wilt caused by $F$. solani in Capsicum spp. are found many countries. Mejía-Batista et al. (2016) identified F. solani as causal agent of wilt in Capsicum chinense in Mexico. Cases of wilt in Capsicum annuum were also reported in Spain (Martinez et al., 2010), China (Duan et al., 2016) and India (Tembhurne et al., 2017).

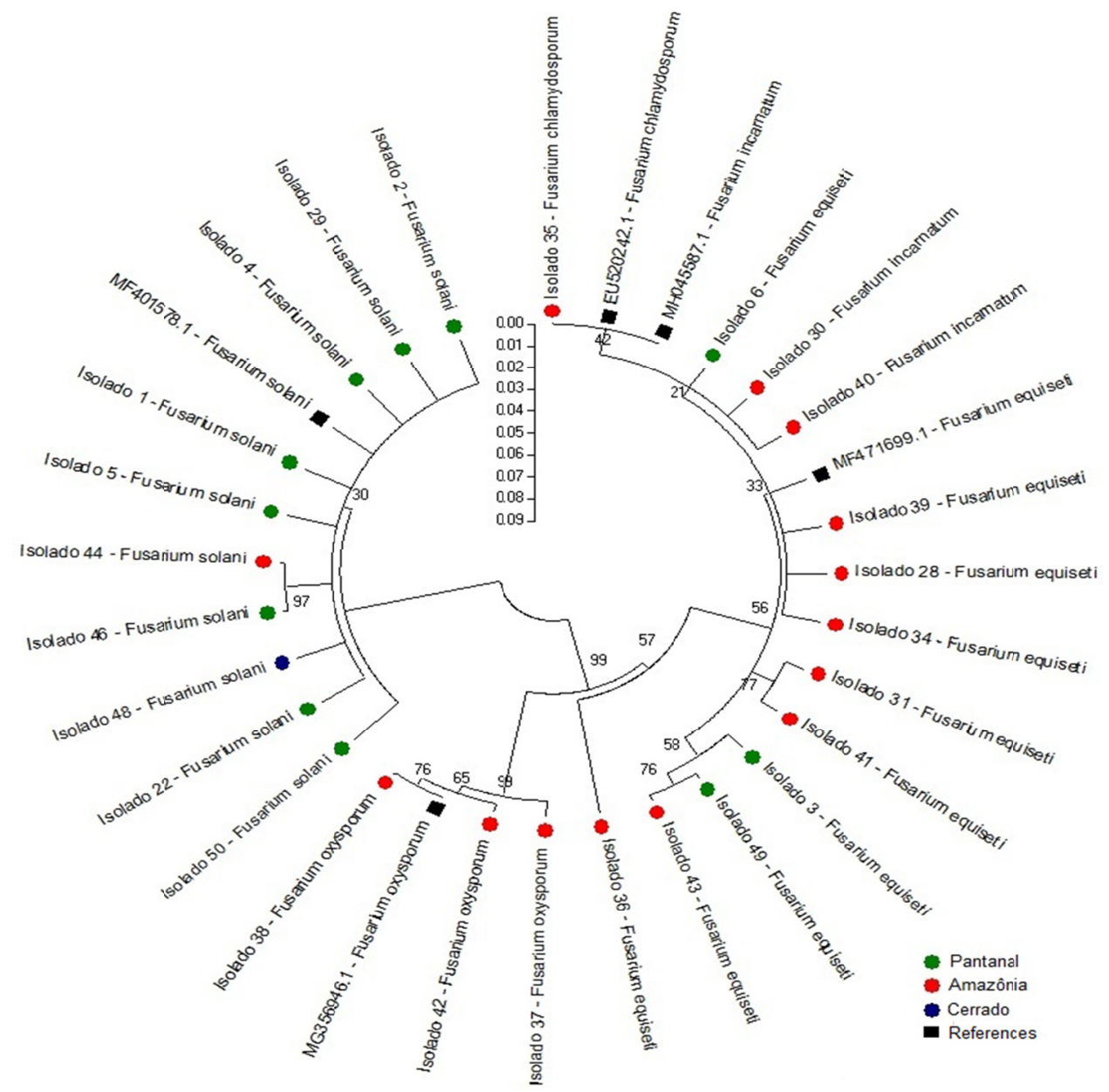

Figure 7. Phylogenetic tree of isolates of Fusarium spp. collected in plants of Capsicum spp. in the biomes of the state of Mato Grosso, Brazil 
Recently the work of Mejía-Batista et al. (2016) found Fusarium equiseti, as well as Fusarium solani, as the causal agent of wilt in Capsicum chinense grown in Mexico.

A first report of occurrence of the pathogen Fusarium incarnatum in C. annuum plants in Trinidad and Tobago named the disease as pepper rot, since it was found in fruits of this crop and caused necrotic lesions (Ramdial et al., 2016). Plants with F. incarnatum presented symptoms of wilting and yellowing.

Fusarium is an important pathogenic fungi genus. It has a conflicting taxonomic history, due to the lack of clear morphological characters separating its species, and its variations and mutations in each host, that end up representing poorly the diversity of Fusarium spp. (Geiser et al., 2004). For example, conflicts in nomenclature are found in the literature; F. incarnatum, F. semitectum and $F$. pallidoroseum are commonly described as the same species (Leslie \& Summerell, 2006). Moreover, Fusarium chlamydosporum, which is found in very few studies, is treated as Fusarium sporotrichioides var. chlamydosporum, and Fusarium fusarioides, according to the Leslie \& Summerell Handbook (2006). This species was found in C. annuum seeds in Pakistan (Sharfun-Nahar et al., 2004).

\section{Conclusions}

Plants of Capsicum spp. with Fusarium spp. were found in the three biomes of the state of Mato Grosso, Brazil. This is probably the first report on the occurrence of Fusarium spp. in Capsicum spp. in Brazil. Sequencing ITS regions was efficient in differentiating the Fusarium species found. Five species of Fusarium were found in plants of Capsicum spp.: F. solani, F. oxysporum, F. equiseti, F. incarnatum and F. chlamydosporum.

\section{References}

Bedendo, I. P. (1995). Podridão de raiz e colo. In A. Bergamin Filho, H. Kimati, \& L. Amorin (Eds.), Manual de Fitopatologia (3rd ed., pp. 829-837). São Paulo:Agronômica Ceres.

Carvalho, J. A. (2015). Reação de espécies de Passiflora a isolados de Fusarium solani e Fusarium oxysporum f. sp. passiflorae, Cáceres (Dissertação, Mestrado em Genética e Melhoramento de Plantas, Universidade do Estado de Mato Grosso).

Chen, C. A., Chang, C. C, Wei, N. V., Chen, C. H., Lein, Y. T., Lin, H., ... Wallace, C. C. (2004). Secondary structure and phylogenetic utility of the Ribossomal Internal Transcribed Spacer 2 (ITS2) in Scleractinian corals. Zoological Studies, 43, 759-771.

Duan, X., Bi, H. G., Li, T., Wu, G. X., Li, Q. M., \& Ai, X. Z. (2017). Root characteristics of grafted peppers and their resistance to Fusarium solani. Biologia Plantarum, 61(3), 579-586. https://doi.org/10.1007/s10535016-0677-4

El Kichaoui, A., Elnabris, K., Shafie, A., Fayyad, N., Arafa, M., \& El Hindi, M. (2017). Development of Beauveria bassiana-Based Bio-Fungicide Against Fusarium Wilt Pathogens for Capsicum annuum, a promising approach toward vital biocontrol Industry in Gaza Strip. IUG Journal of Natural Studies, 25(2), 183-190.

Esri. (2017). ArcGIS Desktop: Release 10.5. Redlands, CA: Environmental Systems Research Institute.

Fungaro, M. H. P. (2000). PCR na Micologia. Biotecnologia Ciência e Desenvolvimento, 14, 12-16.

Geiser, D. M., Jiménez-Gasco, S., Kang, I. Makalowska, N., Veeraraghavan, T. J., Ward, N., Zhang, G. A., \& O’Donnell, K. (2004). FUSARIUM-ID v. 1.0: A DNA sequence database for identifying Fusarium. Eur. $J$. Plant Pathol, 110, 473-479. https://doi.org/10.1023/B:EJPP.0000032386.75915.a0

Gonçalves, A. D. M. (2015). Diversidade de Fusarium oxysporum f. sp. lycopersici e desenvolvimento e validação de marcadores moleculares ligados a genes de resistência em tomateiro (Tese, Doutorado Fitopatologia, Universidade de Brasília). https://doi.org/10.26512/2015.5.T.18691

Hillis, D. M., \& Dixon, M. T. (1991). Ribosomal DNA: Molecular evolution and phylogenetic inference. Quartely Review of Biology, 66(4), 411-453.

Kistler, H. C., Bosland, P. W., Benny, U., Leong, S., \& Williams, P. H. (1987). Relatedness of strains of Fusarium oxysporum from crucifers measured by examination of mitochondrial and ribosomal DNA. Phytopathology, 77(9), 1289-1293. https://doi.org/10.1094/Phyto-77-1289

Leslie, J. F., \& Summerell, B. (2006). Fusarium laboratory manual (p. 387). Blackwell Publishing. https://doi.org/10.1002/9780470278376 
Lievens, B., Rep, M., \& Thomma, B. P. (2008). Recent developments in the molecular discrimination of formae speciales of Fusarium oxysporum. Pest. Manag. Sci., 64, 781-788. https://doi.org/10.1002/ps.1564

Luginbuhl, S. (2010). Fusarium solani-A class project for PP728 Soilborne Plant Pathogens. Retrieved from https://projects.ncsu.edu/cals/course/pp728/Fusarium\%20solani/Fusarium_solani.htm

Martínez, M. A., Martínez, M. C., Bielza, P., Tello, J., \& Lacasa, A. (2011). Effect of biofumigation with manure amendments and repeated biosolarization on Fusarium densities in pepper crops. Journal of Industrial Microbiology \& Biotechnology, 38, 3-11. https://doi.org/10.1007/s10295-010-0826-2

Mejía-Bautista, M. A., Cristóbal-Alejo, J., Tun-Suárez, J. M., \& Reyes-Ramírez, A. (2016). Actividad in vitro de Bacillus spp. en la inhibición de crecimiento micelial de Fusarium equiseti Y Fusarium solani aislado de chile habanero (Capsicum chinense Jacq.). Agrociencia, 50(8).

Menezes, J. P., Lupatini, M., Antoniolli, Z. I., Blume, E., Junges, E., \& Manzoni, C. (2010). Variabilidade genética na região its do rDNA de isolados de Trichoderma spp. (Biocontrolador) e Fusarium oxysporum $\mathrm{f}$. sp. chrysanthemi. Ciência e Agrotecnologia, 34(1), 132-139. https://doi.org/10.1590/S1413-705420100 00100017

Naik, M. K., Devika, G. S., \& Madhukar, H. M. (2008). Identification of resistant sources against wilt of chilli (Capsicum annum L.) caused by Fusarium solani (Mart.) Sacc. J. Mycopathol. Res., 46(1), 93-96.

Nelson, P. E., Toussoun, T. A., \& Marasas, W. F. O. (1983) Fusariurn Species: An illustrated manual for identification. Pennsylvania State University, University Park, PA.

Nirenberg, H. I. (1990). Recent advances in the taxonomy of Fusarium. Studies in Mycology, 32, 91-101

O’donnell, K., Cigelnik, E., \& Casper, H. H. (1998). Molecular phylogenetic, morphological, and mycotoxin data support reidentification of the quorn mycoprotein fungus as Fusarium venenatum. Fungal Genetics and Biology, 23(1), 57-67. https://doi.org/10.1006/fgbi.1997.1018

Ochoa-Alejo, N., \& Ramirez-Malagon, R. (2001). In vitro chili pepper biotechnology. In Vitro Cellular \& Developmental Biology-Plant, 37(6), 701-729. https://doi.org/10.1007/s11627-001-0121-z

Raghu, S., Benagi, V. I., \& Nargund, V. B. (2016). Cultural, morphological and pathogenic variability among the isolates of Fusarium solani causing wilt disease of Chilli (Capsicum annuum L.). Journal of Pure and Applied Microbiology, 10(1), 599-604.

Ramdial, H., Hosein, F., \& Rampersad, S. N. (2016). First report of Fusarium incarnatum associated with fruit disease of bell peppers in Trinidad. Plant Dis, 100, 526-526. https://doi.org/10.1094/PDIS-05-15-0550-PDN

Rocha, F. S., Ferreira, G. H. S., Silva, T. C. S. R., Amaral, F. L., Muniz, M. F. S., \& Pereira, E. A. (2016). Caracterização de Fusarium solani f. sp. piperis, produção de fitotoxina e incidência da fusariose no norte de Minas Gerais. Summa Phytopathologica, 42(1), 67-72. https://doi.org/10.1590/0100-5405/2100

Sahi, I. Y., \& Khalid, A. N. (2007) In vitro biological control of Fusarium oxysporum causing wilt in Capsicum annuum. Mycopath, 5(2), 85-88.

Sharfun-Nahar, S. N., Mushtaq, M., \& Pathan, I. H. (2004). Seed-borne mycoflora of Capsicum annuum imported from India. Pakistan Journal of Botany, 36(1), 191-198.

Silva, A. N., Azevedo G. B., Sobrinho, G. G. R., \& Novaes, Q. S. (2014). Efeito de produtos químicos e de Trichoderma spp. no controle de Fusarium solani do maracujazeiro. Interciencia, 39(6), 398-403.

Singh, J. K., Kumar, M., Kumar, A., \& Mehta, N. (2017). Screening of Chilli Cultivars Against Fusarium Wilt of Chilli (Capsicum annuum L.). International Journal of Agricultural Science and Research, 7(1), 235-240.

Summerell, B. A., Salleh, B., \& John F. (2003). A utilitarian approach to Fusarium identification. Plant Disease, 87(2), 117-128. https://doi.org/10.1094/PDIS.2003.87.2.117

Tamura, K., Peterson, D., Peterson, N., Stecher, G., Nei, M., \& Kumar, S. (2011). MEGA5: Molecular Evolutionary Genetic Analysis using Maximum Likelihood, Evolutionary Distance, and Maximum Parsimony Methods. Molecular Biology and Evolution, 28, 2731-9. https://doi.org/10.1093/molbev/msr121

Teixeira, L. M. (2015). Caracterização de isolados de Fusarium oxysporum e resistência de genótipos de Passiflora à Fusariose (Dissertação, Mestrado Fitopatologia, Universidade Federal de Uberlândia).

Tembhurne, B. V., Belabadevi, B., Kisan, B., Tilak, I. S., Ashwathanarayana, D. S., Suvarna, N., \& Naik, M. K. (2017). Molecular Characterization and Screening for Fusarium (Fusarium solani) Resistance in Chilli 
(Capsicum annuum L.) Genotypes. Int. J. Curr. Microbiol. App. Sci., 6(9), 1585-1597. https://doi.org/ 10.20546/ijcmas.2017.609.195

Vásquez López, A., Tlapal Bolaños, B., Yáñez Morales, M., Pérez Pacheco, R., \& Quintos Escalante, M. (2009) Etiología de la marchitez del'chile de agua' (Capsicum annuum L.) en Oaxaca, México. Revista Fitotecnia Mexicana, 32(2), 127-134.

White, T. J., Bruns, T., Lee, S. J. W. T., \& Taylor, J. W. (1990). Amplification and direct sequencing of fungal ribosomal RNA genes for phylogenetics. PCR protocols: A guide to Methods and Applications, 18(1), 315-322. https://doi.org/10.1016/B978-0-12-372180-8.50042-1

Windels, C. E. (1991). Current status of Fusarium taxonomy. Phytopathology, 81(9), 1048-1051.

\section{Copyrights}

Copyright for this article is retained by the author(s), with first publication rights granted to the journal.

This is an open-access article distributed under the terms and conditions of the Creative Commons Attribution license (http://creativecommons.org/licenses/by/4.0/). 